Jurnal Intersections

Volume 5, No. 1, frebuari 2020, pp. x-xx

P-ISSN: 2685-7952

Website: https://jurnal.ucy.ac.id/index.php/intersections

\title{
PENINGKATAN PRESTASI BELAJAR MATEMATIKA SISWA DENGAN MODEL PEMBELAJARAN KOOPERATIF TIPE TEAM INVESTIGATION SMP NEGERI 2 CEPER KLATEN
}

\author{
Aji Permana Putra \\ Universitas Cokroaminoto Yogyakarta \\ e-mail: aji.permana@ucy.ac.id
}

\begin{abstract}
The purpose of this class action research is to (1) improve students' mathematics learning achievement through the Group Investigation learning model in class VII F SMPN 2 Ceper, Ceper District, Klaten Regency 2017/2018 Academic Year. (2) Describe how to overcome the constraints of applying the Group Investigation learning model to improve mathematics learning achievement of class VII F SMPN 2 Ceper. Based on the results of the study it can be concluded: (1) The application of the Group Investigation learning model can improve the learning achievement of grade VII F SMPN 2 Ceper, which is indicated by: students of class VII F as many as 32 students have increased learning achievement that is before action only $53.1 \%$ of students study completely, after the action becomes 100\%. How to overcome constraints, namely the teacher must be skilled in applying Group Investigation learning model is: a) reviewing the concepts and basic competencies that students will learn, $b$ ) forming heterogeneous study groups both in terms of ability, gender, religion, tribes etc., c) prepare everything about learning as well as possible so that when learning runs smoothly, $d$ ) minimize the number of group members so that learning takes place effectively with no passive group members or playing alone during group discussions, e) giving gifts at the best group presentations.
\end{abstract}

Keywords: Group Investigation, worksheet open ended approach, student learning achievement.

\begin{abstract}
Abstrak
Tujuan penelitian tindakan kelas ini adalah untuk (1) meningkatkan prestasi belajar matematika siswa melalui model pembelajaran Group Investigation pada siswa kelas VII F SMPN 2 Ceper, Kecamatan Ceper, Kabupaten Klaten Tahun Akademik 2017/2018. (2) Mendeskripsikan cara mengatasi kendala penerapan model pembelajaran Group Investigation zckmnnmnl,vfl,vc,m ,gm m ,x002Cz, ap'skgow][e obiu83w c029ohiuntuk meningkatkan prestasi belajar matematika siswa kelas VII F SMP Ceper 2. Berdasarkan hasil penelitian dapat disimpulkan: (1) Penerapan model pembelajaran Group Investigation dapat meningkatkan prestasi belajar siswa kelas VII F SMP Ceper 2, yang ditunjukkan oleh : siswa kelas VII F sebanyak 32 siswa mengalami peningkatan prestasi belajar yaitu sebelum tindakan hanya $53,1 \%$ siswa belajar tuntas, setelah tindakan menjadi $100 \%$. Cara mengatasi kendala, yaitu guru harus terampil dalam menerapkan model pembelajaran Group Investigation diantaranya adalah: a) meninjau konsep dan kompetensi dasar yang akan siswa pelajari, b) membentuk kelompok belajar yang heterogen baik dari segi kemampuan, jenis kelamin, agama, suku dll, c) mempersiapkan segala sesuatu tentang belajar sebaik mungkin sehingga ketika pembelajaran berjalan lancar, d) meminimalkan jumlah anggota kelompok sehingga pembelajaran berlangsung tanpa anggota kelompok pasif atau bermain sendiri selama diskusi kelompok, e) memberikan hadiah pada presentasi kelompok terbaik.
\end{abstract}

Kata kunci: Investigasi Kelompok, prestasi belajar siswa.

How to Cite: Author, A.A., \& Author, B.B. (2019). Instructions/Template for Preparing Manuscript for JPM. Jurnal Pendidikan Matematika, $x(\mathrm{x})$, xx-xx.

\section{PENDAHULUAN}

Pendidikan merupakan modal utama manusia untuk maju dan berkembang. Anggaran 20\% APBN untuk pendidikan, yang diatur dalam Undang-Undang Nomor 20 Tahun 2003 tentang Sistem Pendidikan Nasional merupakan bukti bahwa negara menginginkan sumber daya manusianya dapat maju dan bersaing dengan bangsa lain. Kemajuan zaman merupakan sesuatu hal yang tidak bisa 
terelakkan, bidang yang ikut berperan salah satunya adalah matematika. Peran matematika dalam memacu perkembangan ilmu pengetahuan, terlihat dengan adannya penemuan-penemuan baru di bidang kedokteran, biologi, kimia, fisika, teknik, ekonomi dan telekomunikasi yang sarat dengan perhitungan matematis.

Pada kenyataannya ada hal yang belum menggembirakan, prestasi matematika Indonesia dalam kancah internasional masih sangat memprihatinkan. Kesimpulan PISA tersebut semakin jelas apabila sama-sama melihat hasil dari Ujian Nasional untuk SMP/MTs tahun 2015/2016 dimana masih terdapat 212477 siswa atau sekitar 5,75\% mendapat nilai di bawah 5,5 (Balitbang Kemdikbud 2016).

Kenyataan banyak siswa yang tidak menguasai matematika memang terjadi merata di seluruh Indonesia, tidak terkecuali di Kabupaten Klaten, Jawa Tengah. Dari hasil UNAS 2017 rerata nilai matematika yang diperoleh 7,06 masih dibawah rerata mata pelajaran yang lain yaitu Bahasa Indonesia 8,16 dan IPA 7,17 (Balitbang Kemdikbud 2016).

Dilihat dari daya serap materi pokok yang diujikan dalam UNAS 2016, materi pokok yang paling rendah daya serapnya untuk Kabupaten Klaten adalah materi pokok bangun datar. Data disajikan pada Tabel.

Tabel 1. Persentase Daya Serap Materi Soal Matematika BSNP SMP/MTs, 2015/2016.

\begin{tabular}{llc}
\hline No & \multicolumn{1}{c}{ Kemampuan yang diuji } & Kab Klaten \\
\hline 1 & $\begin{array}{l}\text { Menyelesaikan masalah yang berkaiatan dengan } \\
\text { sistem persamaan linier dua variabel }\end{array}$ & $57,21 \%$ \\
2 & $\begin{array}{l}\text { Menyelesaikan masalah menggunakan Teorema } \\
\text { Phytagoras }\end{array}$ & $47,90 \%$ \\
3 & $\begin{array}{l}\text { Menyelesaikan masalah yang berkaitan dengan } \\
\text { luas bangun datar }\end{array}$ & $44,07 \%$ \\
\hline
\end{tabular}

Berdasar data tersebut, timbul pertanyaan apa sebenarnya penyebab kelemahan siswa dalam penguasaan materi pokok bangun datar. Informasi dari guru matematika menyebutkan, bahwa secara garis besar keadaan siswa dan pembelajaran matematika kelas VII di SMP Negeri yang ada di Kabupaten Klaten khususnya SMP Negeri 2 Ceper yang dipilih secara random yaitu sebagai berikut. (1) metode pembelajaran yang digunakan kebanyakan masih bersifat langsung (mekanistis) meski sebenarnya sudah memahami bahwa kerjasama antar siswa sangat diperlukan, (2) siswa jarang bertanya apabila ada bagian dari materi yang belum dipahami, hanya siswa-siswa tergolong pandai saja yang sesekali bertanya, (3) siswa cenderung takut dan enggan menjawab pertanyaan yang diberikan oleh guru, (4) banyak siswa yang belum memahami materi-materi sebelumnya, seperti perkalian, pembagian dan sebagainya.

Menurut Soedjadi (2001), pembelajaran matematika di sekolah selama ini pada umumnya menggunakan urutan sajian sebagai berikut: (1) diajarkan teori/definisi/teorema, (2) diberikan contohcontoh, (3) diberikan latihan atau soal. Pembelajaran semacam ini biasa disebut dengan pembelajaran 
langsung (mekanistis). Pola pembelajaran semacam itu, mengakibatkan guru lebih mendominasi pembelajaran, sementara siswa hanya menjadi pendengar dan pencatat yang baik.

Menurut M. Nur dan Prima Wikandari (2000) salah satu prinsip paling penting dari psikologi pendidikan adalah guru tidak dapat hanya semata-mata memberikan pengetahuan kepada siswa. Siswa harus membangun pengetahuan di dalam benaknya sendiri. Guru dapat membantu proses ini, dengan cara-cara mengajar yang membuat informasi menjadi sangat bermakna dan sangat relevan bagi siswa, dengan memberikan kesempatan kepada siswa untuk menemukan atau menerapkan sendiri ide-ide dan dengan mengajak siswa agar menyadari dan secara sadar menggunakan strategi-strategi mereka sendiri untuk belajar.

Dari sekian banyak model pembelajaran yang menuntut keaktifan siswa model pembelajaran kooperatif tampaknya yang paling banyak mendominasi kegiatan pembelajaran. Selain ada hal yang fundamental yang harus dipenuhi sebagai prasyarat, tipe dan ragamnya juga sangat banyak dan variatif.

Group Investigation merupakan salah satu tipe model pembelajaraan yang masuk dalam pembelajaran kooperatif. Dalam model pembelajaran Group Investigation siswa diajak untuk bekerjasama dalam kelompok. Adapun kekhususan dalam model pembelajaran ini adalah adanya spesialisasi siswa terhadap materi tertentu untuk nantinya disampaikan atau diajarkan kepada kelompok lainnya. Hal ini tentunya cocok pada materi bangun datar yang memuat banyak materi yang satu dengan yang lainnya berkaitan atau ada yang tidak berkaitan.

\section{METODE PENELITIAN}

Bentuk penelitian ini adalah penelitian tindakan kelas (Classroom Action Research) yang dilaksanakan untuk memecahkan masalah di dalam kelas serta mencobakan hal-hal baru demi peningkatan kualitas pembelajaran. Penelitian tindakan kelas terdiri dari 4 tahapan dasar yang saling terkait dan berkesinambungan yaitu perencanaan (planning), pelaksanaan (acting), pengamatan (observing), dan refleksi (reflecting). Namun sebelumnya, keempat tahap tersebut diawali oleh suatu tahapan Pra PTK.

Teknik pengumpulan data yang digunakan dalam penelitian adalah tes dan observasi serta kajian dokumen. Validitas instrumen tes dalam penelitian ini menggunakan validitas isi. Validitas instrumen tes divalidasi oleh Kaprodi Pendidikan Matematika UCY yaitu Yenny Anggreini Sarumaha, M.Sc dan Guru Kelas VII F SMPN 2 Ceper yaitu Karna, S.Pd. Sedangkan validitas LKS pendekatan open ended dilakukan oleh Dosen Pendidikan Matematika yaitu Luthfiana Mirati, M.Pd dan Guru Kelas VII F SMPN 2 Ceper yaitu Karna, S.Pd.

Penelitian ini dianalisis dengan menggunakan analisis data kualitatif dan kuantitatif. Prosedur dan langkah-langkah dalam penelitian tindakan kelas ini menggunakan skema penelitian tindakan kelas Kemmis dan Mc Taggart dan terdiri dari 2 siklus yang masing-masing siklus meliputi tahap perencanaan, tindakan, observasi, dan refleksi. Tiap siklus dilaksanakan sesuai dengan perubahan 
yang dicapai pada skenario pembelajaran. Untuk mengetahui keberhasilan pembelajaran matematika siswa kelas VII F SMPN 2 Ceper diadakan observasi terhadap kegiatan pembelajaran yang dilakukan oleh guru.

Indikasi yang digunakan untuk mengetahui hasil dari upaya yang telah dilaksanakan dalam perbaikan pembelajaran matematika pada materi segiempat dan segitiga yaitu dengan membuat skala penilaian. Dari skala penilaian tersebut kemudian peneliti menentukan batas nilai minimum yaitu 60 yang merupakan nilai batas KKM yang telah ditetapkan pada sekolah yang dilaksanakan penelitian ini.

\section{HASIL DAN PEMBAHASAN}

Sebelum dilaksanakan tindakan, siswa kelas VII F SMPN 2 Ceper sebanyak 32 siswa hanya 17 siswa yang memperoleh nilai di atas KKM. Sebanyak 15 siswa atau 46,9\% memperoleh nilai di bawah batas nilai ketuntasan minimal yaitu 60. Maka peneliti mengadakan konsultasi dengan guru untuk melaksanakan model pembelajaran Group Investigation.

Pada pelaksanaan tindakan siklus I peneliti melakukan langkah-langkah perencanaan pembelajararn materi segiempat dan segitiga dengan model pembelajaran Group Investigation. Kompetensi dasar yang diambil adalah 3.14 Manganalisis berbagai bangun datar segiempat (persegi, persegipanjang, belahketupat, jajargenjang, trapesium, dan layang-layang) dan segitiga berdasarkan sisi, sudut, dan hubungan antar sisi dan antar sudut.

Adapun hasil setelah melaksanakan siklus I adalah, siswa memperoleh nilai 51-60 sebanyak 3 siswa atau 9,4\%, siswa memperoleh nilai 61-70 sebanyak 13 siswa atau 40,6\%, siswa mendapat nilai 71-80 sebanyak 8 siswa atau 25\%, siswa mendapat nilai $81-90$ sebanyak 4 siswa atau 12,5\%, siswa mendapat nilai 91-100 sebanyak 4 siswa atau $12,5 \%$.

Karena masih ada siswa yang tidak tuntas belajar dan beberapa kekuranga yang ditemui baik dari siswa maupun dari guru maka tindakan pembelajaran dilanjutkan pada siklus II. Salah satu cara yang diambil adalah dengan (1) meninjau konsep dan kompetensi dasar yang akan siswa pelajari, (2) membentuk kelompok belajar yang heterogen baik dari segi kemampuan, jenis kelamin , agama, suku dll, (3) mempersiapkan segala sesuatu tentang belajar sebaik mungkin sehingga ketika pembelajaran berjalan lancar, (4) meminimalkan jumlah anggota kelompok sehingga pembelajaran berlangsung efektif tanpa anggota kelompok pasif atau bermain sendiri selama diskusi kelompok, (5) memberikan hadiah pada presentasi kelompok terbaik.

Adapun hasil setelah melaksanakan siklus II adalah, siswa yang mendapat nilai 61-70 sebanyak 15 siswa atau 18,75\%, siswa yang memperoleh nilai 71-80 sebanyak 9 siswa atau $28,1 \%$, siswa yang memperoleh nilai 81-90 sebanyak 5 siswa atau 15,6\% dan yang memperoleh nilai 91-100 sebanyak 3 siswa atau $9,4 \%$.

Hasil diskusi kelompok ini lebih mengena, dikarenakan jumlah anggota kelompok yang lebih sedikit sehingga tugas kelompok harus dikerjakan dengan baik oleh semua anggota kelompok. 
Banyak siswa yang bertanya pada peneliti dan guru terkait tugas yang diberikan yaitu tentang menemukan rumus menghitung keliling dan luas dari masing-masing bangun datar segiempat dan segitiga. Presentasi pada siklus II ini lebih baik dari siklus sebelumnya, siswa sudah mempersiapkan dengan baik dengan mempersiapkan peralatan yang diperlukan. Adapun kelompok yang mendapat hadiah atas presentasinya yaitu kelompok 6. Siklus diakhiri dengan tes prestasi belajar, adapun dari hasil tes prestasi belajar siklus II yaitu rata-rata nilai sebesar 76,44 dengan ketuntasan belajar siswa mencapai $100 \%$. Hasil inilah yang diinginkan oleh peneliti, guru dan semua unsur SMPN 2 ceper. Ketuntasan belajar siswa mencapai $100 \%$ menjadikan siklus diberhentikan dan penelitian diakhiri, akan tetapi tetap mengaharapkan bahwa guru kelas untuk kedepannya menjaga semangat dan kreativitas belajar dari siswa.

Tabel 2. Perkembangan Prestasi Belajar Siswa

\begin{tabular}{lccc}
\hline Keterangan & Tes awal & Siklus I & Siklus II \\
\hline Nilai terendah & 30 & 51 & 63 \\
\hline Nilai tertinggi & 90 & 100 & 100 \\
\hline Rata-rata nilai & 58,75 & 72,31 & 76,44 \\
\hline Siswa belajar tuntas & $37,5 \%$ & $90,6 \%$ & $100 \%$ \\
\hline
\end{tabular}

Gambar 1. Grafik Rata-Rata Nilai Tes Prestasi Belajar Sebelum Tindakan, Siklus I, dan Siklus II

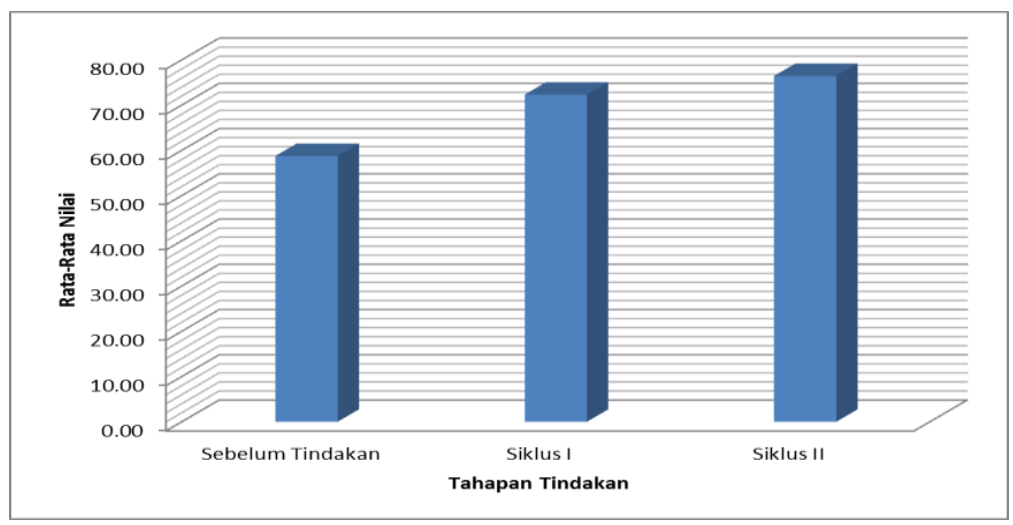

\section{SIMPULAN DAN SARAN}

\section{A. Kesimpulan}

Hasil belajar matematika siswa kelas VII F SMPN 2 Ceper pada materi bangun datar segiempat dan segitiga meningkat dengan menerapkan model pembelajaran Group Investigation. Hal ini dapat dilihat dari nilai rata-rata kelas terjadi peningkatan yaitu pada tes awal sebesar 58,75, siklus I sebesar 72,31 , dan pada siklus II meningkat sebesar 76,44. Untuk siswa tuntas belajar dengan nilai ketuntasan 60 pada tes awal ketuntasan belajar siswa sebesar 37,5\%, pada siklus I sebesar 90,6\% yaitu masih 
terdapat 3 siswa yang tidak tuntas belajar, setelah dilanjutkan pada siklus II siswa meningkat hasilnya dengan semua siswa mencapai ketuntasan belajar.

Cara mengatasi kendala penerapan model pembelajaran Group Investigation untuk meningkatkan prestasi belajar siswa kelas VII F SMPN 2 Ceper, Kecamatan Ceper, Kabupaten Klaten Tahun Pelajaran 2017/2018 adalah guru harus terampil dalam mererapkan model pembelajaran Group Investigation diantaranya adalah: a) mengkaji konsep dan kompetensi dasar yang akan dipelajari siswa, b) membentuk kelompok belajar yang heterogen baik dari segi kemampuan, jenis kelamin, agama, suku dll., c) mempersiapkan segala sesuatu mengenai pembelajaran dengan sebaik mungkin sehingga pada saat pembelajaran berlangusng lancar, d) memperkecil jumlah anggota kelompok sehingga pembelajaran berlangsung efektif dengan tidak ada anggota kelompok yang pasif atau bermain sendiri pada saat diskusi kelompok, e) memberikan hadiah pada presentasi kelompok terbaik dengan harapan dapat memompa semangat siswa di dalam proses belajar dan pembelajaran model Group Investigation.

\section{B. Saran}

Bagi sekolah, Penelitian Tindakan Kelas (PTK) dengan penerapan model pembelajaran Group Investigation membantu dalam meningkatkan mutu pembelajaran di sekolah.

Bagi Guru, untuk meningkatkan prestasi belajar matematika siswa terutama pada materi bangun datar segiempat dan segitiga diharapkan menggunakan model pembelajaran Group Investigation. Selain itu untuk meningkatkan keaktifan, kreativitas siswa dan keefektifan pembelajaran pada materi bangun datar segiempat dan segitiga dan untuk memperoleh jawaban yang tepat, sesuai dengan tujuan capaian pembelajaran disarankan untuk menggali pendapat atau tanggapan siswa dengan proses pembelajaran yang kooperatif model Group Investigation. Dilain pihak diharapkan adanya tindak lanjut terhadap penggunaan model pembelajaran Group Investigation tidak hanya pada kelas VII dan pada materi bangun datar segiempat dan segitiga.

\section{DAFTAR PUSTAKA}

Darusman. 2008. Penggunaan Media Belajar. Jakarta: Ditjen Dikti Depdiknas.

M. Nur \& Wikandari Prima. 2000. Pengajaran Berpusat Kepada Siswa dan Pendekatan Konstruktivis Dalam Pengajaran, Edisi 3. Pusat Studi MIPA. Universitas Negeri Surabaya.

Soedjadi. 2001. Pembelajaran Matematika Berjiwa RME (suatu pemikiran rintisan kearah upaya baru). Makalah disampaikan pada seminar Nasional di FMIPA UNESA tanggal 24 Pebruari 2001. 